\title{
MENGANALISIS PERKEMBANGAN MEDIA PEMBELAJARAN MATEMATIKA TERHADAP HASIL BELAJAR BERBASIS GAME
}

\section{ANALYSIS OF THE DEVELOPMENT OF MATHEMATICS LEARNING MEDIA ON GAME-BASED LEARNING OUTCOMES}

\author{
Uswatun Hasanah \\ Universitas \\ Labuhanbatu, \\ Indonesia ${ }^{1}$ \\ email: \\ uswa78hasanah@gmail \\ .com \\ Islamiani Safitri ${ }^{2}$ \\ Universitas \\ Labuhanbatu, \\ Indonesia $^{2}$ \\ email: \\ islamiani.safitri@gmail. \\ com \\ Rukiah $^{3}$ \\ Universitas \\ Labuhanbatu, \\ Indonesia ${ }^{3}$ \\ email: \\ rukiahnst201@gmail.co \\ $\underline{m}$ \\ Marwah Nasution ${ }^{4}$ \\ Universitas \\ Labuhanbatu \\ email: \\ nasutionmarwah317@g \\ mail.com \\ IJI Publication \\ p-ISSN: 2774-1907 \\ e-ISSN: 2774-1915 \\ Vol. 1, No. 3, pp. 204- \\ 211, Juli 2021

\footnotetext{
Unit Publikasi Ilmiah

Unit Publikasi Ilmiah

Indonesia
}

Abstrak: Pengembangan Media Games dalam Pembelajaran sangat pesat bagi setiap tenaga pendidik untuk mengikuti kemajuan teknologi berbasis game terhadap hasil belajar siswa. Penelitian ini bertujuan untuk mengetahui hasil perkembangan media game di era 4.0 Media pembelajaran yang baik ialah media pembelajaran yang mampu memberikan rangsangan kepada siswa sehingga dapat membangkitkan minat belajar siswa. Metode penelitian yang dipilih dalam penelitian ini ialah metode SLR (Systematic Literature Review). Pengumpulan data dilakukan dengan mendokumentasi dan mereview semua artikel terkait pendidikan matematika dalam kurun waktu 2012 - 2020. Artikel yang digunakan pada penelitian ini sebanyak 30 artikel jurnal nasional dan internasional terakreditasi yang diperoleh dari Google Schoolar, Research Gate, SINTA, DOAJ, dan Scopus. Media pembelajaran game merupakan suatu alternatif yang dapat mengatasi permasalahan siswa dalam menghadapi pelajaran matematika. Dengan media pembelajaran game, siswa dapat mengubah pola pikir dan kreativitas belajar menjadi lebih menyenangkan. Dengan adanya pembelajaran media berbasis game siswa dapat meningkatkan inovatif, kreatif, sehingga mencapai hasil belajar siswa.

Kata Kunci: Pendidikan Matematika Berbasis Game, Media Pembelajaran Game, Systematic literatur Review

Abstract: The development of Media Games in Learning is very rapid for every educator to follow the progress of game-based technology on student learning outcomes. This study aims to determine the results of the development of game media in the $4.0 \mathrm{era}$. Good learning media are learning media that are able to provide stimulation to students so that they can arouse student interest in learning. The research method chosen in this study is the SLR (Systematic Literature Review) method. Data collection was carried out by documenting and reviewing all articles related to mathematics education in the period $2012-2020$. The articles used in this study were 30 accredited national and international journal articles obtained from Google Schoolar, Research Gate, SINTA, DOAJ, and Scopus. Game learning media is an alternative that can overcome students' problems in dealing with mathematics lessons. With game learning media, students can change the mindset and creativity of learning to be more fun. With the game-based learning media students can improve innovative, creative, so as to achieve student learning outcomes.

Keywords: Game-Based Mathematics Education, Game Learning Media, Systematic Literature Review.

\section{PENDAHULUAN}

Matematika merupakan ilmu yang mempelajari tentang logika mengenai bentuk, besaran dan konsep-konsep yang berhubungan satu dengan yang lainnya. Matematika memiliki objek kajian yang abstrak, mendasarkan diri pada kesepakatan dengan menggunakan pola pikir dedukatif dan dijiwai dengan kebenaran konsistensi.

Media pembelajaran adalah sarana atau alat bantu pendidikan yang dapat digunakan sebagai perantara dalam proses pembelajaran untuk mempertinggi efektifitas dan efisiensi dalam mencapai tujuan pengajaran (Sanaky, 2013). Media pembelajaran dapat mempertinggi proses belajar siswa dalam pengajaran yang pada gilirannya diharapkan dapat mempertinggi hasil belajar yang dicapainya (Sudjana dan Rivai, 2010). Dalam memilih media untuk kepentingan pengajaran sebaiknya memperhatikan kriteria-kriteria sebagai berikut (Sudjana dan Rivai, 2010): (1) ketepatan dengan tujuan pembelajaran, (2) dukungan terhadap isi pembelajaran, 
kemudahan memperoleh media,

keterampilan guru dalam menggunakannya, (5) ketersediaan waktu, dan (6) kesesuaian dengan tearaf berfikir siswa.

Media pembelajaran merupakan alternatif atau alat bantu yang dapat digunakan untuk memahami kemampuan pembelajaran serta dapat mendorong siswa dalam proses belajar matematika Berikut ini adalah beberapa definisi-definisi menurut para ahli media pembelajaran berbasis game. Menurut Miarso (2004) berpendapat bahwa "Media pembelajaran adalah segala sesuatu yang digunakan untuk mengalirkan pesan serta dapat membangkitkan pikiran, perasaan, perhatian, dan kemauan belajar sehingga dapat mendorong terjadinya proses belajar". Handriyantini

(2009) mengemukakan bahwa game edukasi adalah salah satu jenis media yang digunakan dalam memberikan pengajaran yang berupa permainan dengan tujuan untuk merangsang daya pikir dan meningkatkan konsentrasi melalui media yang unik dan menarik. Pengertian ini tentu saja mengidentifikasikan bahwa game edukasi bertujuan untuk menunjang proses belajar mengajar dengan kegiatan yang menyenangkan dan lebih kreatif. Sedangkan menurut Marc Prensky (2012), definisi game edukasi adalah suatu bentuk permainan (game) yang didesain atau dibuat untuk tujuan belajar, akan tetetap dalam game edukasi biasanya menawarkan bermain untuk bersenang-senang. Novia Desta (2016), arti game edukasi adalah permainan yang dibuat dengan tujuan pembelajaran yang bukan hanya bermaksud menghibur sehingga diharpakan bisa menambah wawasan pengetahuan. "Permainan matematika adalah sesuatu kegiatan yang menyenangkan (menggembirakan) yang dapat menunjang tercapainya tujuan instruksional dalam pengajaran matematika baik aspek kognitif, afektif, maupun psikomotorik". (Ruseffendi, 2006). Berdasarkan pernyataan tersebut, bahwa setiap permainan tidak bisa disebut permainan matematika. Karena permainan matematika bukan sekedar membuat siswa senang dan tertawa, tetapi harus menunjang tujuan instruksional pengajaran matematika baik aspek kognitif, afektif, maupun kognitif. Dimana aspek kognitif itu sendiri adalah segi kemampuan yang berkenaan dengan pengetahuan, penalaran atau pikiran. Menurut Bloom (dalam Dimyati dan Mudjiono, 1999), "Aspek kognitif terdiri dari 6 kategori, yaitu pengetahuan, pemahaman, penerapan, analisis, sintesis, dan evaluasi". Aspek afektif adalah kemampuan yang mengutamakan perasaan, emosi, dan reaksireaksi yang berbeda dengan penalaran.

Menurut Krathwohl dkk. (dalam Dimyati dan Mudjiono, 1999), "Aspek afektif terdiri dari lima kategori yaitu penerimaan, partisipasi, penilaian, penentuan sikap, organisasi dan pembentukan pola". Sedangkan aspek psikomotorik adalah kemampuan yang mengutamakan keterampilan jasmani. Menurut Symposium (Dimyati dan Mudjiono, 1999), "Ranah psikomotorik terdiri dari tujuh kategori yaitu persepsi, kesiapan, gerakan terbimbing, gerakan terbiasa, gerakan kompleks, penyesuaian pola gerakan, dan kreativitas". Selain itu, penempatan penggunaan permainan matematika harus sesuai, jangan salah waktu dan tempat.

Pada kenyataan yang ditemukan bahwa sebagian besar peserta didik yang mengikuti pembelajaran kurang mampu dalam memecahkan masalah matematika seperti yang diharapkan. Hal ini terlihat dari hasil belajar peserta didik yang rendah. Materi yang tersedia dalam kegiatan belajar mengajar pun sangat padat dalam memenuhi kurikulum di sekolah. Gejala ini membuat peserta didik mendapat kesulitan belajar ketika menghadapi ujian karena penguasaan materi pelajaran yang mudah hilang dalam waktu singkat dengan materi kajian yang begitu padat. 
Pendidikan matematika yang monoton membuat peserta didik bosan dan umumnya menganggap matematika sebagai pelajaran yang menyeramkan dan merasa soal matematika sulit untuk dikerjakan. Tidak jarang guru pun sering kali mengalami kesulitan memecahkan soal matematika, ketika mendapatkan pertanyaan soal yang sulit dari peserta didik, berbagai alasan yang guru berikan untuk tidak menjawab karena malu untuk mengatakan "tidak tahu". Hal itu menjadikan penghambat dalam bidang mentransfer ilmu, karena bagi peserta didik, guru adalah salah satu sarana untuk mendapatkan informasi yang mereka ingin ketahui lebih dalam. Maka dari itu media pembelajaran berbasis game ini sangat membantu tenaga pendidik dan siswapun belajar tidak terlalu monoton.

Pada umumnya pembelajaran matematika di Indonesia masih menekankan menghafal rumus-rumus. Bahkan, guru pun otoriter dengan keyakinan pada rumus atau pengetahuan matematika yang sudah ada. Padahal pembelajaran matematika itu harus mengembangkan logika, pemikiran, dan berargumentasi. Sekarang ditambah malah harus bisa meyakinkan orang lain, ini tidak pernah dikembangkan dalam pendidikan matematika di sekolah. Kelemahan utama buruknya pembelajaran matematika akibat kualitas guru matematika yang rendah. Karena itu penguatan kualitas guru matematika perlu diprioritaskan. Terdapat faktor internal non kognitif yang berpengaruh besar terhadap hasil belajar matematika, yaitu efikasi diri atau keyakinan untuk mencapai keinginan yang dikehendaki.

Tanpa disadari game membawa dampak positif bagi semuanya, salah satunya adalah pendidikan. Banyak anak yang lupa untuk belajar karena terlalu asik dengan permainan game mereka. Tetapi apabila game dibuat untuk sarana pembelajaran, maka game dapat menjadi cara menyenangkan untuk belajar, game sendiri akan dapat menghadirkan suasana berbeda dalam kegiatan pendidikan.

\section{METODE}

Artikel ilmiah ini disusun dengan menggunakan metode Systematic Literature Review (SLR). Menurut Agusta, (2007) mengenai metode penelitian : "Literature Review is a critical analysis of the research conducted on a particular topic or question in the field of science" yang artinya Literature Review merupakan analisa kritis dari penelitian yang sedang dilakukan terhadap topik khusus atau berupa pertanyaan terhadap suatu bagian dari keilmuan. Literature Review membantu kita dalam menyusun kerangka berfikir yang sesuai dengan teori, temuan, maupun hasil penelitian sebelumnya dalam menyelesaikan rumusan masalah pada penelitian yang kita buat. Metode SLR digunakan untuk mengidentifikasi, mengkaji, mengevaluasi, dan menafsirkan semua penelitian yang tersedia dengan bidang topik fenomena yang menarik, dengan pertanyaan penelitian tertentu yang relevan. Dengan penggunaan Metode SLR dapat dilakukan review dan identifikasi jurnal secara sistematis. Untuk merampungkan penelitian ini, peneliti mengumpulkan artikel jurnal dari Google Schoolar, Research Gate, SINTA, DOAJ, dan Scopus. Kata kunci adalah Pendidikan Matematika Berbasis Game, dan Media Pembelajaran Game. Artikel yang dikumpulkan hanya artikel yang dipublikasikan dalam rentang waktu 2012 hingga 2020. Dari berbagai artikel, peneliti memilih 30 artikel yang terkait erat dengan kata kunci yang digunakan. Langkah selanjutnya, peneliti mengelompokkan artikel-artikel yang berkaitan dengan pendidikan media pembelajaran berbasis game. 


\section{HASIL DAN DISKUSI}

Pendidikan Matematika Berbasis Game merupakan salah satu jawaban dalam menerapkan proses belajar mengajar yang aktif dan efektif terutama pembelajaran matematika. Game merupakan media pembelajaran alternatif atau alat bantu yang dapat digunakan untuk memahami kemampuan siswa dalam proses belajar matematika yang menyenangkan (menggembirakan) serta dapat menunjang tercapainya tujuan instruksional dalam pengajaran matematika.

Adapun data hasil penelitian yang dimasukkan dalam artikel ini adalah analisis dan rangkuman dari artikel yang didokumentasi terkait dengan Pendidikan Matematika Berbasis Game.

Tabel 1

Hasil Penelitian terkait Pendidikan Matematika Berbasis Game

\begin{tabular}{|c|c|c|}
\hline $\begin{array}{c}\text { Peneliti \& } \\
\text { Tahun }\end{array}$ & Jurnal & Hasil Penelitian \\
\hline $\begin{array}{l}\text { Zetra Hainul } \\
\text { Putra, } \\
\text { Darmawijoyo, } \\
\text { Ratu Ilma } \\
\text { Indra Putri, } \\
\text { Jaap den } \\
\text { Hertog., } 2011 \\
\end{array}$ & $\begin{array}{l}\text { Indo MS. } \\
\text { J.M.E }\end{array}$ & $\begin{array}{l}\text { Penelitian yang kami gunakan adalah penelitian } \\
\text { desain dengan penerapan game burung beo ini } \\
\text { juga dapat meningkatkan pemahaman siswa } \\
\text { terhasap pasangan bilangan } 10 \text { dalam } \\
\text { menyelesaikan permasalahan penjumlahan dan } \\
\text { pengurangan }\end{array}$ \\
\hline $\begin{array}{l}\text { Ratu Ilma } \\
\text { Indra Putri, } \\
\text { Zulkardi., } \\
2020\end{array}$ & $\begin{array}{l}\text { Journal on } \\
\text { Mathematics } \\
\text { Education }\end{array}$ & $\begin{array}{l}\text { Penelitian ini menggunakan metode design } \\
\text { research dengan sistem lesson study selama } \\
\text { tahap pendesainan dan implementasi. } \\
\text { Berdasarkan hasil penelitian menunjukkan } \\
\text { bahwa soal matematika tipe PISA pada konten } \\
\text { uncertainty and data telah valid, praktis, dan } \\
\text { memiliki efek potensial. Selain itu melalui soal } \\
\text { tipe PISA menggunakan konteks Asian siswa } \\
\text { dapat belajar kolaboratif sehingga proses belajar } \\
\text { menjadi bermakna dan mudah. }\end{array}$ \\
\hline $\begin{array}{l}\text { Steffi Claudia, } \\
\text { Ajeng Ayu } \\
\text { Widiastuti, } \\
\text { Mozes } \\
\text { Kurniawan., } \\
2018\end{array}$ & $\begin{array}{l}\text { Jurnal Obsesi : } \\
\text { Jurnal } \\
\text { Pendidikan } \\
\text { Anak Usia } \\
\text { Dini }\end{array}$ & $\begin{array}{l}\text { Pengumpulan Data menggunakan wawancara, } \\
\text { observasi dan dokumentasi. Teknik Analisis } \\
\text { Data menggunakan Deskriptif Kuantitatif. } \\
\text { Disimpulkan bahwa meningkatnya kemampuan } \\
\text { motorik halus anak pada tahap pratindakan } \\
\text { yaitu rata-rata } 33,3 \% \text { menjadi } 65,38 \% \text { pada } \\
\text { tindakan siklus I, lalu meningkat menjadi } \\
79,62 \% \text { dalam tahap siklus II. }\end{array}$ \\
\hline $\begin{array}{l}\text { Sangsoon } \\
\text { Lim., } 2017\end{array}$ & $\begin{array}{l}\text { International } \\
\text { Journal of } \\
\text { Electrical and } \\
\text { Computer } \\
\text { Engineering } \\
\text { (IJECE) }\end{array}$ & $\begin{array}{l}\text { Penerapan pendekatan pembelajaran } \\
\text { matematika dalam radio kognitif. ini juga } \\
\text { membuktikan bahwa permainan potensial dapat } \\
\text { mencapai keseimbangan Nash ketika pengguna } \\
\text { yang tidak egois mengambil strategi egois untuk } \\
\text { memaksimalkan keuntungan bagi si pengguna. }\end{array}$ \\
\hline $\begin{array}{l}\text { Josephine } \\
\text { Kusuma, } \\
\text { Sulistiawati., } \\
2014\end{array}$ & $\begin{array}{l}\text { Indo MS- } \\
\text { JME }\end{array}$ & $\begin{array}{l}\text { Metode yang digunakan dalam penelitian ini } \\
\text { adalah design research. Metode ini terdiri tiga } \\
\text { tahapan, yaitu preliminary design, teaching } \\
\text { experiment dan retrospective analysis.Instrumen } \\
\text { yang digunakan dalam penelitian ini berupa } \\
\text { instrument tes tertulis dan tes lisan. Instrumen } \\
\text { ini digunakan untuk mengukur kemampuan } \\
\text { mencongak dan kemampuan mengajarkan } \\
\text { materi. Hasil dari penelitian ini menunjukkan } \\
\text { bahwa Matematika GASING dapat membantu } \\
\text { mahasiswa dalam memahami perkalian } \\
\text { bilangan } 1 \text { sampai } 10 \text { dan mampu mengajarkan } \\
\text { perkalian bilangan } 1 \text { sampai } 10 \text { dengan lebih } \\
\text { baik. }\end{array}$ \\
\hline $\begin{array}{l}\text { M. Rohwati., } \\
2012\end{array}$ & $\begin{array}{l}\text { Jurnal } \\
\text { Pendidikan } \\
\text { IPA Indonesi }\end{array}$ & $\begin{array}{l}\text { Data kualitatif yang diperoleh dari non tes } \\
\text { menggunakan analisis deskripsi kualitatif } \\
\text { berdasarkan hasil observasi refleksi tiap siklus. } \\
\text { Tujuan dari penelitian yaitu untuk } \\
\text { meningkatkan hasil belajar siswa dengan } \\
\text { memanfaatkan media game education akan } \\
\text { sangat membantu pelaksanaan kegiatan belajar } \\
\text { mengajar yang efektif, menyenangkan dan } \\
\text { edukatif. }\end{array}$ \\
\hline $\begin{array}{l}\text { Farida } \\
\text { Nursyahidah, } \\
\text { Ratu Ilma }\end{array}$ & Indo MS-JME & $\begin{array}{l}\text { Penelitian yang digunakan adalah design } \\
\text { research dari penelitian menunjukkan bahwa } \\
\text { kemampuan pemahaman siswa terhadap konsep }\end{array}$ \\
\hline
\end{tabular}

\begin{tabular}{|c|c|c|}
\hline $\begin{array}{l}\text { Indra Putri, } \\
\text { Somakim., } \\
2013\end{array}$ & & $\begin{array}{l}\text { penjumlahan bilangan sampai } 20 \text { dapat } \\
\text { dirangsang dengan menggunakan dakocan } \\
\text { sebagai konteks dalam pembelajaran }\end{array}$ \\
\hline $\begin{array}{l}\text { Anton Jaelani, } \\
\text { Ratu Ilma } \\
\text { Indra Putri, } \\
\text { Yusuf } \\
\text { Hartono., } 2013 \\
\end{array}$ & $\begin{array}{l}\text { Indo MS. } \\
\text { J.M.E }\end{array}$ & $\begin{array}{l}\text { Penelitian yang digunakan adalah design } \\
\text { research kesimpulan bahwa desain pembelajaran } \\
\text { ini dapat membantu perkembangan siswa untuk } \\
\text { memahami konsep kekonstanan dalam satuan } \\
\text { standar serta mengukur satuan standar dalam } \\
\text { permainan gasing tradisional }\end{array}$ \\
\hline $\begin{array}{l}\text { S.Wardani,L. } \\
\text { Lindawati*,S. } \\
\text { B.W. } \\
\text { Kusuma., } 2019\end{array}$ & $\begin{array}{l}\text { Jurnal } \\
\text { Pendidikan } \\
\text { IPA Indonesia }\end{array}$ & $\begin{array}{l}\text { Penelitian ini menggunakan desaign reseacrch } \\
\text { tujuan dari penelitian ini yaitu mengetahui } \\
\text { peingkatan kemampuan berpikir kritis peserta } \\
\text { didik pada kategori efektif melalui hasil } \\
\text { belajarnya melalui game CBG (Chemistry Board } \\
\text { Game) }\end{array}$ \\
\hline $\begin{array}{l}\text { F.Adnan,B. } \\
\text { Prasetyo, } \\
\text { Nuriman., } \\
2017 \\
\end{array}$ & $\begin{array}{l}\text { Jurnal } \\
\text { Pendidikan } \\
\text { IPA Indonesia } \\
\end{array}$ & $\begin{array}{l}\text { Penggunaan aplikasi game Bana sebagai media } \\
\text { pembelajaran referensi desain pengembangan } \\
\text { game edukasi dapat meningkatkan kemampuan } \\
\text { hasil belajar berpikir kritis siswa }\end{array}$ \\
\hline $\begin{array}{l}\text { A. N. M. } \\
\text { Fauziah, A. R. } \\
\text { Purnomo, N. } \\
\text { Fathonah, } \\
\text { Khusaini., } \\
2018\end{array}$ & $\begin{array}{l}\text { Jurnal } \\
\text { Pendidikan } \\
\text { IPA Indonesia }\end{array}$ & $\begin{array}{l}\text { Penelitian yang digunakan adalah desaign } \\
\text { research penelitian ini bertujuan untuk } \\
\text { mendeskripsikan pemanfaatan MLG untuk } \\
\text { meningkatkan nilai kualifikasi kompetensi yang } \\
\text { harus dicapai siswa }\end{array}$ \\
\hline $\begin{array}{l}\text { A.Lestari,A. } \\
\text { Widiyatmoko, } \\
\text { S. } \\
\text { Alimah,I.Juliy } \\
\text { ani., } 2015\end{array}$ & $\begin{array}{l}\text { Jurnal } \\
\text { Pendidikan } \\
\text { IPA Indonesia }\end{array}$ & $\begin{array}{l}\text { Penelitian yang digunakan adalah desaign } \\
\text { research penelitian ini bertujuan untuk } \\
\text { mengefektifan prestasi belajar dan respon siswa } \\
\text { terhadap pembelajaran dikategorikan baik } \\
\text { melalui game tournament dengan media Flash } \\
\text { Card }\end{array}$ \\
\hline $\begin{array}{l}\text { Puji Astuti., } \\
2014\end{array}$ & IndoMS-JME & $\begin{array}{l}\text { Hasil penelitian menggambarkan bagaimana } \\
\text { siswa mengembangkan pemahaman desimal } \\
\text { satu digit. Untuk mencapai tujuan tersebut, } \\
\text { Local Instruction Theory (LIT) tentang proses } \\
\text { belajar desimal dan sarana yang dirancang } \\
\text { untuk mendukung pembelajaran tersebut } \\
\text { dikembangkan. Seiring dengan ide ini, teori } \\
\text { Pendidikan Matematika Realistik (RME) } \\
\text { diusulkan. }\end{array}$ \\
\hline $\begin{array}{l}\text { P.D.A.Putra1, } \\
\text { M. Iqbal., } \\
2016\end{array}$ & $\begin{array}{l}\text { Jurnal } \\
\text { Pendidikan } \\
\text { IPA Indonesia }\end{array}$ & $\begin{array}{l}\text { Tujuan dari penelitian ini adalah untuk } \\
\text { menerapkan Serious Game berbasis Taman } \\
\text { Nasional Baluran untuk meningkatkan } \\
\text { kemampuan berpikir kreatif dan motivasi belajar } \\
\text { siswa. }\end{array}$ \\
\hline $\begin{array}{l}\text { Rio Caesar., } \\
2015\end{array}$ & $\begin{array}{l}\text { Journal of } \\
\text { Animation and } \\
\text { Games Studies }\end{array}$ & $\begin{array}{l}\text { Genre (kategori) dalam video game juga } \\
\text { mengalami perkembangan yang pesat } \\
\text { bersamaan dengan berkembanganya video game } \\
\text { juga dipengaruhi oleh perkembangan pesat dari } \\
\text { teknologi perangkat yang diciptakan dalam } \\
\text { sejarah perkembangan game dari masa ke masa. }\end{array}$ \\
\hline $\begin{array}{l}\text { Fajar Khoirul } \\
\text { Fahmi,2016 }\end{array}$ & $\begin{array}{l}\text { Jurnal Media } \\
\text { Games } \\
\text { Education. } \\
\text { Journal of } \\
\text { Media Games } \\
\text { Education }\end{array}$ & $\begin{array}{l}\text { Pengembangan game edukasi matematika untuk } \\
\text { peserta didik kelas IV SD ini bertujuan untuk } \\
\text { memberikan gambaran yang menyeluruh } \\
\text { tentang bagaimana proses mengembangkan } \\
\text { game edukasi matematika, yang pada akhirnya } \\
\text { menghasilkan suatu media berupa game } \\
\text { education untuk kelas IV SD dengan pokok } \\
\text { bahasaan perkalian }\end{array}$ \\
\hline $\begin{array}{l}\text { Wahyu } \\
\text { Ananda } \\
\text { Putri,2018 }\end{array}$ & $\begin{array}{l}\text { Jurnal } \\
\text { Pendidikan } \\
\text { Matematika }\end{array}$ & $\begin{array}{l}\text { Produk media pembelajaran matematika board } \\
\text { game "The Labyrinth of Trigonometri" materi } \\
\text { trigonometri kelas X SMA bahwa media board } \\
\text { game "The Labyrinth of Trigonometri" valid, } \\
\text { praktis, dan efektif untuk digunakan dalam } \\
\text { pembelajaran matematika khususnya pada } \\
\text { materi trigonometri. }\end{array}$ \\
\hline $\begin{array}{l}\text { Mei Andini, } \\
\text { Tri Nova Hasti } \\
\text { Yunianta, } \\
2018\end{array}$ & $\begin{array}{l}\text { Jurnal } \\
\text { Pendidikan } \\
\text { Matematika }\end{array}$ & $\begin{array}{l}\text { bahwa media board game "Petualangan } \\
\text { Aljabar" valid dari aspek materi dan media } \\
\text { pembelajaran dengan persentase } 95 \% \text { dan } 96 \% \\
\text { keduanya termasuk dalam kategori sangat } \\
\text { setuju. }\end{array}$ \\
\hline $\begin{array}{l}\text { Meinita Yesi } \\
\text { Anugrahini; } \\
\text { Y.Windrawant } \\
\text { o,2017 }\end{array}$ & $\begin{array}{l}\text { Pendidikan } \\
\text { Matematika }\end{array}$ & $\begin{array}{l}\text { produk media pembelajaran game bubble match } \\
\text { dapat dikembangkan menggunakan desain } \\
\text { pengembangan ADDIE (analysis, design, } \\
\text { development, implementation, dan evaluation). }\end{array}$ \\
\hline $\begin{array}{l}\text { Tarmidzi } \\
\text { Ramadhan } \\
\text { Ade } \\
\text { Amirulloh, } \\
\text { Medika } \\
\text { Risnasari, , } \\
\text { Puji Rahayu } \\
\text { Ningsih, 2019 } \\
\end{array}$ & $\begin{array}{l}\text { Jurnal Ilmiah } \\
\text { Edutic }\end{array}$ & $\begin{array}{l}\text { Game edukasi "Pecahan Smart Edukasi" layak } \\
\text { digunakan untuk diterapkan dalm proses } \\
\text { pembelajaran. }\end{array}$ \\
\hline Suwiyadi,2012 & $\begin{array}{l}\text { Jurnal } \\
\text { Matematika }\end{array}$ & $\begin{array}{l}\text { Berdasarkan hasil analisis structural equation } \\
\text { model (SEM) disimpulkan sebagai berikut. a) } \\
\text { Pengaruh yang terbesar yang membangun } \\
\text { konstruk variabel kompetensi adalah indikator } \\
\text { kompetensi profesional sementara pengaruh } \\
\text { terkecil adalah kompetensi pedagogic, Pengaruh } \\
\text { yang terbesar yang membangun konstruk } \\
\text { variabel motivasi kerja guru adalah kemandirian } \\
\text { dalam bertindak sementara, b) pengaruh terkecil } \\
\text { adalah tanggung jawab dalam melakukan kerja } \\
\text { c) Pengaruh yang terbesaryang membangun } \\
\text { konstruk guru yang inovatif indikator } \\
\text { melakukan kegiatan kreatif sementara pengaruh } \\
\text { terkecil adalah menemukan strategi, metode, \& } \\
\text { konsep. }\end{array}$ \\
\hline $\begin{array}{l}\text { Indah } \\
\text { Rahmawati, } \\
\text { Ibut Priono } \\
\text { Leksono, } \\
\text { Harwanto,202 } \\
1\end{array}$ & $\begin{array}{l}\text { Jurnal Kajian } \\
\text { Teknologi } \\
\text { Pendidikan }\end{array}$ & $\begin{array}{l}\text { Hasil penelitian pengembangan Game } \\
\text { Petualang Pembelajaran Berhitung untuk } \\
\text { Sekolah Dasar (SD) ini dapat disimpulkan } \\
\text { bahwa Penelitian dan Pengembangan ini } \\
\text { menghasilkan produk berupa game petualang } \\
\text { berhitung untuk kelas 5 Sekolah Dasar (SD). }\end{array}$ \\
\hline
\end{tabular}


p-ISSN: 2774-1907; e-ISSN: 2774-1915; Vol.1, No.3, Juli 2021

\begin{tabular}{|c|c|c|}
\hline $\begin{array}{l}\text { Sarifa Suhra, } \\
\text { Dedi } \\
\text { Djubaedi,Dedi } \\
\text { Djubaedi,2020 }\end{array}$ & $\begin{array}{l}\text { Jurnal } \\
\text { Pendidikan } \\
\text { Islam, } 2020\end{array}$ & $\begin{array}{l}\text { Permainan tradisional Bugis mappasajang dapat } \\
\text { dilakukan oleh peserta didik laki-laki dan } \\
\text { perempuan. Permainan tradisional Bugis } \\
\text { tersebut sarat dengan nilai-nilai karakter. } \\
\text { Permainan taradisonal Bugis mappasajang } \\
\text { berkontribusi bagi penguatan pendidikan } \\
\text { karakter. Hal itu tampak dalam berbagai aspek } \\
\text { kehidupan masyarakat, seperti dalam bidang } \\
\text { pendidikan, sosial, ekonomi, dan kesehatan. }\end{array}$ \\
\hline $\begin{array}{l}\text { Vina Anggia } \\
\text { Nastitie } \\
\text { Ariawan } 1^{*} \\
\text { Inne } \\
\text { Marthyane } \\
\text { Pratiwi, } 2017\end{array}$ & $\begin{array}{l}\text { Jurnal Prima } \\
\text { Edukasia }\end{array}$ & $\begin{array}{l}\text { Pembelajaran GASING dilakukan dengan } \\
\text { tahapan-tahapan yang unik yaitu konkret, } \\
\text { abstrak, dan mencongak. Tahap konkret adalah } \\
\text { mendorong siswa untuk mengeksplorasi dengan } \\
\text { benda-benda konkret. Setelah tahap konkret } \\
\text { selesai, selanjutnya adalah tahap abstrak. } \\
\text { Selanjutnya, siswa menuju tahap ketiga yaitu } \\
\text { mereka dapat menghitung mencongak dan } \\
\text { cepat. Dengan tahapan-tahapan tersebut, siswa } \\
\text { dapat memahami matematika dengan jelas dan } \\
\text { mudah. Metode yang digunakan dalam } \\
\text { penelitian ini adalah design research. Metode ini } \\
\text { terdiri tiga tahapan, yaitu preliminary design, } \\
\text { teaching experiment dan retrospective analysis. } \\
\text { Sampel dari penelitian ini adalah } 14 \text { orang } \\
\text { mahasiswa tahun pertama (kelas matrikulasi) di } \\
\text { STKIP Surya, Tangerang, Banten. Instrumen } \\
\text { yang digunakan dalam penelitian ini berupa } \\
\text { instrument tes tertulis dan tes lisan. Instrumen } \\
\text { ini digunakan untuk mengukur kemampuan } \\
\text { mencongak dan kemampuan menajarkan } \\
\text { materi. }\end{array}$ \\
\hline $\begin{array}{l}\text { Novia Novia, } \\
\text { Anna } \\
\text { Permanasari, } \\
\text { Riandi Riandi, } \\
\text { Ida Kaniawati, } \\
2020\end{array}$ & $\begin{array}{l}\text { Jurnal Inovasi } \\
\text { Pendidikan } \\
\text { IPA }\end{array}$ & $\begin{array}{l}\text { Education game ini untuk mengetahui } \\
\text { penggunaan teknologi berupa educational game } \\
\text { dapat meningkatkan kreativitas siswa dalam } \\
\text { pembelajaran di kelas karna memberikan sebuah } \\
\text { pandangan untuk peneliti, desainer game, } \\
\text { pengembang di bidang educational game dan } \\
\text { kreativitas. }\end{array}$ \\
\hline $\begin{array}{l}\text { Muchamad } \\
\text { Arif, Medika } \\
\text { Risnasari, } \\
2016\end{array}$ & $\begin{array}{l}\text { Jurnal Ilmiah } \\
\text { Edutic }\end{array}$ & $\begin{array}{l}\text { Berdasarkan yang telah dilakukan pada siswa } \\
\text { dan guru menunjukan bahwa permainan } \\
\text { Mr.Moo memperoleh nilai } 3.12 \text { dari segi } \\
\text { deainnya, itu berarti Mr.Moo adalah permainan } \\
\text { yang baik dan cocok untuk siswa sekolah dasar. } \\
\text { Dan dari isinya atau materinya, Mr.Moo } \\
\text { mendapatkan nilai } 3,45 \text { yang berarti bahwa } \\
\text { Mr.Moo adalah cara yang efektif untuk } \\
\text { meningkatkan ketrampilan siswa dalam } \\
\text { menghitung disekolah dasar. }\end{array}$ \\
\hline $\begin{array}{l}\text { Dwi } \\
\text { Krisbiantoro, } \\
\text { Deny } \\
\text { Haryono, } \\
2017\end{array}$ & $\begin{array}{l}\text { Jurnal } \\
\text { Telemaika }\end{array}$ & $\begin{array}{l}\text { Melalui game matematika ini dapat memberikan } \\
\text { pengaruh terhadap peningkatan pemahaman } \\
\text { siswa kelas } 2 \text { SD Negeri } 2 \text { Pamijen Kec. } \\
\text { Baturraden sebesar } 10 \% \text {. }\end{array}$ \\
\hline $\begin{array}{l}\text { Ulya Za'im } \\
\text { Luthfya, } 2020\end{array}$ & $\begin{array}{l}\text { Jurnal } \\
\text { Pendidikan } \\
\text { Matematika }\end{array}$ & $\begin{array}{l}\text { MLG yang dimainkan untuk mendukung siswa } \\
\text { dalam mempelajari topik energi panas dan } \\
\text { alirannya mampu mempromosikan tiga } \\
\text { kompetensi sesuai standar Kurikulum } 2013 \text {; } \\
\text { kompetensi sikap, psikomotor, dan kognitif. } \\
\text { Ada dua keuntungan menggunakan game ini. } \\
\text { Pertama, informasi yang disajikan pada kartu } \\
\text { dapat mendorong siswa untuk menyadari dan } \\
\text { mengenali apa yang penting itu. Dengan begitu, } \\
\text { mereka bisa mengelola ilmunya untuk } \\
\text { memahami konsep. Selain itu, siswa juga } \\
\text { menggunakan keterampilan metode ilmiah } \\
\text { untuk menghasilkan hipotesis dan kesimpulan. } \\
\text { Dengan kata lain, hal ini akan mempengaruhi } \\
\text { aspek kognitif dan psikomotor secara } \\
\text { bersamaan. Kedua, aturan MLG yang } \\
\text { ditetapkan oleh siswa dapat menjadikan siswa } \\
\text { jujur dan bertanggung jawab atas perannya. Hal } \\
\text { ini mempengaruhi sikap siswa. }\end{array}$ \\
\hline $\begin{array}{l}\text { Untung Ali } \\
\text { Miftahuddin, } \\
\text { Hobri, Randi } \\
\text { Pratama } \\
\text { Murtikusuma, } \\
2019\end{array}$ & $\begin{array}{l}\text { Vygotsky } \\
\text { Journal }\end{array}$ & $\begin{array}{l}\text { Game android yang telah dikembangkan dalam } \\
\text { penelitian ini memiliki keunggulan dalam } \\
\text { penggunaan yaitu pengguna dapat } \\
\text { menggunakan media pembelajaran dimanapun } \\
\text { tanpa menggunakan jaringan internet sehingga } \\
\text { lebih efisien dan biasa menghasilkan suatu } \\
\text { produk tertentu yang akan diuji kevalidan, } \\
\text { kepraktisan dan keefektifan. }\end{array}$ \\
\hline $\begin{array}{l}\text { Ma'sum, M. } \\
\text { Yusuf } \\
\text { Romdoni, } \\
\text { Rendi } \\
\text { Hermanto, } \\
2018\end{array}$ & $\begin{array}{l}\text { Jurnal Ilmiah } \\
\text { Sains \& } \\
\text { Teknologi }\end{array}$ & $\begin{array}{l}\text { Game edukasi Trigonorendi merupakan game } \\
\text { single player berbasis web berjenis quis yang } \\
\text { didalamnya berisi materi tentang trigonometri } \\
\text { dalam pelajaran matematika yang bertujuan } \\
\text { untuk mengubah anggapan yang tadinya materi } \\
\text { trigonometri itu yang paling sulit menjadi } \\
\text { mudah untuk dipelajari dan dipahami. }\end{array}$ \\
\hline
\end{tabular}

Berdasarkan hasil penelitian yang telah dilakukan sebagaimana tercantum pada tabel di atas, menunjukkan bahwa penggunaan pendidikan matematika berbasis game terbukti dapat meningkatkan pemahaman siswa terhadap pasangan bilangan 10 dalam menyelesaikan permasalahan penjumlahan dan pengurangan (Zetra Hainul Putra, Darmawijoyo, Ratu Ilma Indra Putri, Jaap den Hertog., 2011), siswa dapat belajar kolaboratif sehingga proses belajar menjadi bermakna dan mudah, (Ratu Ilma Indra Putri, Zulkardi, 2020), media board game "Petualangan Aljabar" valid dari aspek materi dan media pembelajaran dengan persentase $95 \%$ dan 96\% keduanya termasuk dalam kategori sangat setuju, (Mei Andini, Tri Nova Hasti Yunianta 2018), produk media pembelajaran game bubble match dapat dikembangkan menggunakan desain pengembangan ADDIE (analysis, design, development, implementation, dan evaluation), (Meinita Yesi Anugrahini; Y. Windrawanto, 2017), game edukasi "Pecahan Smart Edukasi" layak digunakan untuk diterapkan dalm proses pembelajaran, (Tarmidzi Ramadhan Ade Amirulloh, Medika Risnasari, Puji Rahayu Ningsih, 2019). Hasil penelitian pengembangan Game Petualang Pembelajaran Berhitung untuk Sekolah Dasar (SD) meyimpulkan bahwa pengembangan ini menghasilkan produk berupa game petualang berhitung untuk kelas 5 Sekolah Dasar (SD), (Indah Rahmawati, Ibut Priono Leksono, Harwanto, 2021). Permainan tradisional Bugis Mappasajang dapat dilakukan oleh peserta didik laki-laki dan perempuan. Permainan tradisional Bugis tersebut sarat dengan nilai-nilai karakter. Permainan taradisonal Bugis Mappasajang berkontribusi bagi penguatan pendidikan karakter. Hal itu tampak dalam berbagai aspek kehidupan masyarakat, seperti dalam bidang pendidikan, sosial, ekonomi, dan kesehatan, (Sarifa Suhra, Dedi Djubaedi, 2020. Pembelajaran Gasing dilakukan dengan tahapan-tahapan yang unik yaitu konkret, abstrak, dan mencongak. Tahap konkret adalah mendorong siswa untuk mengeksplorasi dengan benda-benda konkret. Setelah tahap konkret selesai, selanjutnya adalah tahap abstrak. Selanjutnya, siswa menuju tahap ketiga yaitu mereka dapat menghitung 
mencongak dan cepat. Dengan tahapantahapan tersebut, siswa dapat memahami matematika dengan jelas dan mudah, (Vina Anggia Nastitie Ariawan, Inne Marthyane Pratiwi, 2017). Education game ini untuk mengetahui penggunaan teknologi berupa educational game dapat meningkatkan kreativitas siswa dalam pembelajaran di kelas karna memberikan sebuah pandangan untuk peneliti, desainer game, pengembang di bidang educational game dan kreativitas, (Novia Novia, Anna Permanasari, Riandi Riandi, Ida Kaniawati, 2020). Game android yang telah dikembangkan dalam penelitian ini memiliki keunggulan dalam penggunaan yaitu pengguna dapat menggunakan media pembelajaran dimanapun tanpa menggunakan jaringan internet sehingga lebih efisien dan biasa menghasilkan suatu produk tertentu yang akan diuji kevalidan, kepraktisan dan keefektifan, (Untung Ali Miftahuddin, Hobri, Randi Pratama Murtikusuma, 2019). Game edukasi Trigonorendi merupakan game single player berbasis web berjenis Quis yang didalamnya berisi materi tentang trigonometri dalam pelajaran matematika yang bertujuan untuk mengubah anggapan yang tadinya materi trigonometri itu yang paling sulit menjadi mudah untuk dipelajari dan dipahami, (Ma'sum, M. Yusuf Romdoni, Rendi Hermanto, 2018). Penggunaan aplikasi game Bana sebagai media pembelajaran referensi desain pengembangan game edukasi dapat meningkatkan kemampuan hasil belajar berpikir kritis siswa, (F. Adnan, B. Prasetyo, Nuriman, 2017).

Berdasarkan hasil penelitian yang telah dilakukan sebagaimana tercantum pada tabel di atas, penelitian desain dengan penerapan game burung beo ini juga dapat meningkatkan pemahaman siswa terhasap pasangan bilangan 10 dalam menyelesaikan permasalahan penjumlahan dan pengurangan, (Zetra Hainul Putra, Darmawijoyo, Ratu Ilma Indra Putri, Jaap den Hertog, 2011). Penelitian yang digunakan adalah design research dari penelitian menunjukkan bahwa kemampuan pemahaman siswa terhadap konsep penjumlahan bilangan sampai 20 dapat dirangsang dengan menggunakan dakocan sebagai konteks dalam pembelajaran, (Farida Nursyahidah, Ratu Ilma Indra Putri, Somakim, 2013), desain pembelajaran ini dapat membantu perkembangan siswa untuk memahami konsep kekonstanan dalam satuan standar serta mengukur satuan standar dalam permainan gasing tradisional, (Anton Jaelani, Ratu Ilma Indra Putri, Yusuf Hartono, 2013).

\section{KESIMPULAN}

Dari pembahasan di atas maka dapat disimpulkan bahwa pendidikan pembelajaran berbasis game yaitu dapat meningkatkan pemahaman pelajar terhadap pembelajaran matematika melalui pembelajaran berbasis game. Sehingga pembelajaran matematika ini tidak terlalu membosankan seperti biasanya dengan adanya pembelajaran berbasis game dapat membantu menyenangkan proses belajar yang efektif serta dapat mengasah berpikir kritis pelajar dalam mempelajari pelajaran matematika menjadi lebih baik.

\section{REFERENSI}

A.Lestari, A. (2015). Pembelajaran Suara Menggunakan Tim Game Turnamen Dengan Flash Card Sebagai Media Di SMP 13 Magelang. Jurnal Pendidikan IPA Indonesia, IV(2), 177-184.

A.N.M.Fauziah, A. (2018). Penggunaan Monopoli Like Game (MLG) Untuk Mempromosikan Skor Berkualitas Untuk Tiga Kompetensi Siswa. Jurnal Pendidikan IPA Indonesia, VII(3), 280285.

Anton Jaelani, R. I. (2013). Strategi Siswa Mengukur Waktu Menggunakan Permainan Gasing Tradisional di Kelas 
III Sekolah Dasar. IndoMS. J.M.E, IV(1), 29-40.

Anugrahini, M. Y., \& Y.Windrawanto. (2017). Pengembangan Game Bubble Match Sebagai Media Pembelajaran Pembagian Dalam Bentuk Pengurangan Berulang Untuk Siswa Kelas 2 SD. Jurnal Pendidikan Matematika, IV(1), 7583.

Astuti, P. (2014). Memepelajari Angka Desimal Satu Digit Dengan Pengukuran Dan Panjang Prediksi Game. IndoMS.J.M.E, V(1), 34-46.

Caesar, R. (2015). Kajian Pustaka Pekembangan Genre Games Dari Masa Ke Masa. Jurnal Animasi dan Pendidikan Game, I(2), 100-113.

Dwi Krisbiantoro, D. H. (2017). Game Matematika Sebagai Upaya Peningkatan Pemahaman Matematika Siswa Sekolah Dasar. Jurnal Telematika, $X(2), 1-11$.

F.Adnan, B. N. (2017). Analisis Uji Usaha

Pada Game Bana Sebagai Refrensi Desain Game Edukasi Di SMP. Jurnal Pendidikan IPA Indonesia, VI(1), 88-94.

Fahmi, F. K. (2016). Pengembangan Media Games Education Dalam Pembelajaran Matematika. Jurnal Games Education, I(2), 215-226 .

Farida Nursyahidah, R. I. (2013). Mendukung Pemahaman Tambahan Siswa Kelas 1 sampai 20 Dengan Game Tradisional. IndoMS J.M.E, IV(2), 212223.

Indah Rahmawati, I. P. (2020). Pengembangan Game Petualang untuk Pembelajaran Berhitung. Jurnal Kajian

Teknologi Pendidikan, V(1), 11-23.

Josephine Kusuma, S. (2014). Mengajar Multiplikasi Angka 1 sampai 10 Kepada Mahasiswa STIKIP Surya Menggunakan Matematika Gasing. IndoMS J.M.E, V(1), 66-84.

Lim, S. (2017). Alokasi Saluran Teori Permainan Di Jaringan Radio Kognitif.
International Journal of Electrical and Compuret Engineering (IJECE), VII(2), 986-991.

Luthfya, U. Z. (2020). Pengembangan Game Edukasi "Beruang Pintar (Belajar Bangun Ruang Pintar)" untuk Memfasilitasi Pemahaman Konsep. Jurnal Pendidikan Matematika, VIII(1), 289-299.

Ma'sum, M. Y. (2018). Game Edukasi Trigonometri Berbasis Web Untuk Media Pembelajaran. Jurnal Ilmiah Sains \& Teknologi, II(1), 92-105.

Mei Andini, T. N. (2018). Pengembangan Game Board"Petualangan Aljabar" dalam Pembelajaran Matematika SMA. Jurnal Pendidikan Matematika, IX(2), 95105.

Muchamad Arif, M. R. (2016). Penerapan Teknologi Game Berhitung Untuk Meningkatkan Kemampuan Matematika Pada Siswa Tingkat Sekolah Dasar. Jurnal Ilmiah Edutic, III(1), 48-57.

Novia Novia, A. P. (2020). Tren Penelitian Educational Game Untuk Peningkatan Kreativitas Siswa: Sebuah Systematic Review Dari Literatur. Jurnal Inovasi Pendidikan IPA, VI(2), 217-226.

P.D.Putra, M. (2016). Implementasi Serius Game Terinspirasi Taman Nasional Baluran Untuk Meningkatkan Kemampuan Berfikir Kritis. Jurnal Pendidikan IPA Indonesia, V(1), 101-108. PutrI, W. A. (2018). Pengembangan Media

Pembelajaran Board Game "The Labyrinth of Trigonometry"Padamateri Trigonometri Kelas X SMA. Jurnal Pendidikan Matematika, XXXIV (2), 88100.

Ratu Ilma Indra Putri, Z. (2020). Merancang Tugas Matematika Seperti Pisa Menggunakan Konteks Asian Games. Jurnal Pendidikan Matematika, XI(1), 135144. 
Rohwati, M. (2012). Penggunaan Pendidikan Game untuk Meningkatkan Hasil Belajar IPA Biologi Konsep Klasifikasi Makhluk Hidup. Jurnal Pendidikan IPA Indonesia, I(1), 75-81.

S.Wardani, L. L. (2017). Pengembangan Ingkuiri Dengan Menggunakan Game Kemistri Board Berbasis Android untuk Meningkatkan Hasil Belajar dan Kemampuan Berfikir Kritis. Jurnal Pendidikan IPA Indonesia, VI(2), 196-205.

Sarifa Suhra, D. D. (2020). Kontribusi Permainan Tradisional Bugis dalam Penguatan Pendidikan Karakter siswa di Madrasah. Jurnal Pendidikan Islam, VI(2), 233-244.

Steffi Claudia, A. A. (2018). Game Origami untuk Meningkatkan Kerampilan Motorik Halus Anak Usia 4-5 Tahun di Desa Gang Buaya Salatiga. Jurnal Obsesi Jurnal Pendidikan Anak Usia Dini, II(2), 143-148.

Suwiyadi. (2012). Model Kinerja Guru Matematika SMK Kota Semarang. Jurnal Penelitian Pendidikan, xxix(1), 6674.

Tarmidzi Ramadhan Ade Amirulloh, M. R. (2019). Pengembangan Game Edukasi Matematika (Operasi Bilangan Pecahan) Berbasis Android Untuk Sekolah Dasar. Jumal Ilmiah Edutic, $V(2), 115-123$.

Untung Ali Miftahuddin, H. R. (2019). Pengembangan Game Android Berbantuan Software Construct 2 Pada Materi Pola Bilangan. Vygotsky Journal, I(2), 74-86.

Vina Anggia Nastitie Ariawan, I. M. (2017).

Menerapkan Strategi Pembelajaran Gembira menggunakan Metode Treasure Clue Game Dalam Rangka Meningkatkan Keterampilan Pemahaman Membaca. Jurnal Prima Edukasia, V(2), 203-210.

Zetra Hainul Putra, D. R. (2001). Siswa Kelas Satu Mempelajari Fakta Angka Hingga
10 Menggunakan Game Parrot.

IndoMS. J.M.E, II(2), 163-172. 